\title{
MENINGKATKAN KEAKTIFAN BELAJAR SISWA PADA KOMPETENSI DASAR ORGANISASI PELAJARAN PKN MELALUI PENDEKATAN PEMBELAJARAN PAKEM UNTUK KELAS III SD NEGERI 060819 KEC. MEDAN KOTA
}

\author{
Ratna Dewi \\ Surel: ratnadewi02@yahoo.com
}

\begin{abstract}
ABSTRAK
Tujuan penelitian ini adalah untuk meningkatkan keaktifan belajar siswa dengan penerapan pendekatan pembelajaran PAKEM pada pelajaran PKn Kelas III SD Negeri 060819 Kec. Medan Kota. Jenis penelitian ini adalah Penelitian Tindakan Kelas (Classroom Action Research). Subjek penelitian ini adalah siswa kelas III SD Negeri 060819 Kec. Medan Kota dengan jumlah sampel sebanyak 22 orang siswa tahun ajaran 2017/2018. Berdasarkan analisis data diperoleh bahwa dari 22 orang siswa pada kondisi awal drata-rata skor aktifitas belajar siswa sebesar 9 dan 77, 27\% kategori kurang aktif. Pada Siklus I Pertemuan 1 diperoleh rata-rata skor keaktifan belajar siswa sebesar 10 dan 68,18\% kategori kurang aktif, pada siklus I pertemuan 2 meningkat menjadi 13 dan 50\% termasuk kategori cukup aktif. Pada Siklus II Pertemuan 1 diperoleh rata-rata skor aktifitas belajar siswa sebesar 16 dan 40,91\% sudah termasuk kategori aktif, pada Siklus II Pertemuan 2 skor aktifitas belajar semakin meningkat menjadi 19 termasuk kategori aktif dan 45,45\% siswa yang termasuk kategori sangat aktif. Dengan demikian dapat disimpulkan bahwa dengan penerapan pendekatan pembelajaran PAKEM dapat meningkatkan keaktifan belajar siswa pada pelajaran PKn di kelas III SD Negeri 060819 Kec. Medan Kota T.A. 2017/2018.
\end{abstract}

Kata Kunci: Keaktifan Belajar, PKn, PAKEM

\section{PENDAHULUAN}

Pelajaran PKn ini merupakan bagian dari pendidikan sejak dahulu hingga sekarang, dimana PKn secara formal diberikan kepada siswa secara berkesinambungan mulai dari jenjang pendidikan sekolah dasar sampai perguruan tinggi.

Guru professional hendaknya mampu memikul dan melaksanakan tanggung jawab sebagai guru kepada peserta didik. Guru harus menjadi motivator, yang mendorong membantu, dan mengarahkan peserta didik untuk mengalami proses pembelajaran sesuai dengan minat, bakat, potensi, perkembangan fisik, dan psikologisnya, dalam hal ini dibutuhkan sosok guru yang mampu memahami potensi peserta didik dengan baik sehingga mampu melayani peserta didik dengan baik sehingga mampu melayani peserta didik sesuai dengan kebutuhan dan karakteristiknya. Salah satu realitas dalam pendidikan yang sukar 
diingkari dewasa ini adalah ciutnya peran guru dalam proses pengembangan potensi peserta didik. Sebagian besar yang dilakukan guru tidak lain dari pada menyajikan pengetahuan jadi yang harus diketahui dan dihafalkan oleh peserta didik. Fenomena semacam ini sudah merupakan tradisi di persekolahan khususnya pembelajaran PKn di sekolah dasar (SD). Dengan adanya anggapan dikalangan siswa bahwa ilmu pengetahuan social merupakan mata pelajaran yang menjenuhkan dan kurang menantang minat belajar siswa, bahkan dipandang sebagai mata pelajaran kelas dua.

Hasil observasi awal guru di SD Negeri 060819 Kec. Medan Kota ditemukan bahwa dalam pengajaran PKn, guru kurang mendorong dan melibatkan siswa secara aktif dalam belajar. Keaktifan siswa dalam pembelajaran PKn cenderung kurang khususnya pada materi pokok organisasi. Metode yang digunakan guru kurang bervariasi. Guru hanya menggunakan metode ceramah dengan menjelaskan materi di depan kelas kemudian meminta siswa mengerjakan tugas-tugas yang ada di dalam buku paket atau buku pegangan. Kegiatan pembelajaran ini, membuat siswa tampak kurang aktif dalam belajar. Ciri-ciri siswa yang tidak aktif dalam belajar diantaranya adalah kegiatan yang dilakukan siswa hanya mendengarkan dan mencatat, tidak bertanya atau meminta penjelasan baik dari temannya maupun dari guru, siswa hanya diam ketika ditanya sudah mengerti atau belum, dan siswa tidak mengemukakan pendapat. Seperti yang diteliti di Kelas III SD ini, dimana kebanyakan siswa tampak kurang bersemangat, mengantuk, dan merasa bosan dengan pembelajaran yang berlangsung. Selain itu, pengguna metode atau model yang digunakan guru ketika mengajar kurang tepat sehingga membuat siswa kurang menyenangi pembelajaran PKn. Jika siswa kurang menyenangi proses pembelajaran PKn maka keaktifan belajar siswa juga akan berkurang dan pemahaman siswa juga rendah terhadap pelajaran PKn.

Keaktifan belajar siswa di dalam belajar PKn sangat diperlukan. Karena, keaktifan siswa dalam proses pembelajaran merupakan keterlibatan siswa dalam bentuk sikap, pikiran, atau perbuatan siswa itu sendiri. Dengan adanya keaktifan belajar siswa, maka kegiatan pembelajaran PKn di SD akan terlihat lebih aktif dalam pembelajaran. Salah satu cara untuk meningkatkan keaktifan belajar siswa adalah dengan menerapkan pendekatan pembelajaran PAKEM. Menurut Rose dan Nocholl (2003:84) dengan menerapkan pendekatan, pembelajaran akan lebih menarik dan menyenangkan karena proses pembelajaran akan lebih bervariasi, 
santai, dan santai, baik digunakan dalam menunujukkan prestasi, dapat memacu aktivitas belajar siswa agar lebih aktif, meningkatkan semangat siswa dalam proses belajar mengajar.

Pembelajaran

PAKEM

sebagai pendekatan mengajar yang digunakan bersama metode tertentu dan berbagai media pengajaran yang disertai penataan lingkungan sedemikian rupa agar proses pembelajaran menjadi aktif, kreatif, efektif, dan menyenangkan. Dengan demikian, para siswa merasa tertarik dan mudah menyerap pengetahuan dan keterampilan yang diajarkan. Selain itu, PAKEM juga memungkinkan siswa melakukan kegiatan yang beragam untuk mengembangkan sikap, pemahaman, dan keterampilannya sendiri dalam arti tidak semata-mata "disuapi" guru. PAKEM lebih memungkinkan guru dan siswa berbuat kreatif bersama. Guru mengupayakan segala cara secara kreatif untuk melibatkan semua siswa dalam proses pembelajaran. Sementara itu, peserta didik juga didorong agar kreatif dalam berinteraksi dengan sesame teman, guru, materi pelajaran dan segala alat bantu belajar, sehingga hasil pembelajaran dapat meningkat. Berdasarkan latar belakang di atas, maka peneliti tertarik untuk melakukan Penelitian Tindakan Kelas dengan judul : "Meningkatkan Keaktifan Belajar Siswa Pada
Kompetensi Dasar Organisasi Pelajaran PKN Melalui Pendekatan Pembelajaran PAKEM Untuk Kelas III SD Negeri 060819 Kec. Medan Kota TA. 2017/2018”.

Berdasarkan latarbelakang masalah di atas, masalah yang diidentifikasi adalah:

1. Kurang aktifnya siswa di dalam kelas.

2. Kekreatifan siswa kurang aktif terlihat selama kegiatan pembelajaran PKn.

3. Siswa kurang memahami konsep materi pembelajaran organisasi.

4. Penggunaan metode atau model pembelajaran yang kurang tepat membuat pelajaran kurang disenangi siswa.

5. Rendahnya pemahaman siswa terhadap pelajaran PKn.

6. Metode yang digunakan guru dalam mengajar kurang bervariasi hanya menggunakan metode ceramah.

Tujuan yang hendak dicapai dalam penelitian ini adalah untuk meningkatkan keaktifan belajar siswa dengan menerapkan pendekatan pembelajaran PAKEM pada materi pokok organisasi di Kelas III SD Negeri 060819 Kec. Medan Kota.

Manfaat yang diharapkan dari hasil penelitian ini adalah sebagai berikut:

1. Bagi siswa, menambah pengetahuan dan pengalaman 
belajar dalam meningkatkan keaktifan belajar PKn.

2. Memberdayakan siswa agar lebih kreatif dalam berinteraksi dengan sesame teman, guru, materi pelajaran dan segala alat bantu belajar, agar hasil pembelajaran dapat meningkat.

3. Bagi sekolah, sebagai bahan masukan dalam meningkatkan kualitas dan mutu sekolah melalui peningkatan prestasi belajar siswa dan kinerja guru karena kualitas proses pembelajaran dikelola oleh guru yang profesional.

4. Bagi guru, menjadi bahan masukan untuk meningkatkan mutu pengajaran PKn dengan pengajaran yang aktif, kreatif, dan menyenangkan.

5. Sebagai salah satu bahan usul kenaikan pangkat satu tingkat.

\section{METODE PENELITIAN}

Jenis penelitian yang dilakukan dalam penelitian ini adalah penelitian tindakan kelas (classroom) yang mengarah kepada keaktifan belajar siswa melalui penerapan pendekatan pembelajaran PAKEM. Penelitian ini dilaksanakan di Kelas III SD Negeri 060819 Kec. Medan Kota Pelaksanaan penelitian direncanakan selama 3 bulan pada tanggal Pebruari - April 2016 mulai kegiatan persiapan sampai pelaksanaan tindakan.
Subyek yang melaksanakan tindakan dalam penelitian ini adalah guru bekerjasama dengan guru kelas sebagai observer. Sedangkan objek yang dikenai tindakan dalam penelitian ini adalah siswa Kelas III SD yang berjumlah 22orang di SD Negeri 060819 Kec. Medan Kota Tahun Ajaran 2017/2018.

Sesuai dengan jenis penelitian, yaitu penelitian tindakan kelas maka dalam desain penelitian ini memiliki tahap-tahap seperti yang dikemukakan oleh Arikunto (2008:16) secara garis besar terdapat empat tahapan yang dilalui dalam melaksanakan tindakan kelas, yaitu (1) perencanaan (planning), pelaksanaan (acting), (3) pengamatan (observing), dan refleksi (reflecting). Adapun model dan penjelasan untuk masing-masing tahap adalah sebagai berikut:

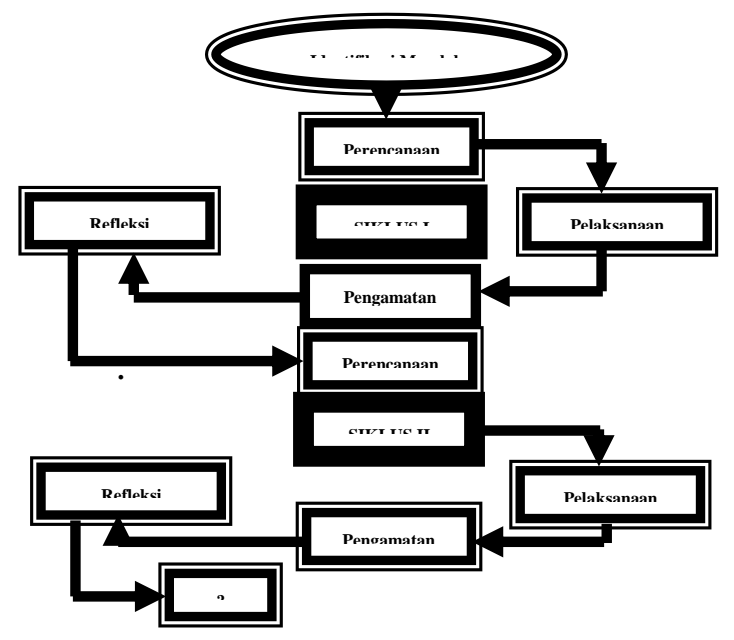

Gambar 3.1. (Model Desain Penelitian Menurut Arikunto) Sumber: Suharsimi (2006: 23) 
Sesuai dengan jenis penelitian ini yaitu penelitian tindakan kelas, maka penelitian ini memiliki tahaptahap penelitian yang berupa siklussiklus. Penelitian tindakan kelas dilakukan sekurang-kurangnya dalam dua siklus tindakan yang beruntutan. Informasi dari siklus yang trdahulu sangat menentukan bentuk siklus berikutnya. Oleh karena itu, siklus yang kedua, ketiga dan seterusnya tidak dirancang sebelum siklus pertama untuk perencanaan siklus berikutnya Arikunto (2006 : 23).

Dalam penelitian ini peneliti terlebih dahulu melaksanakan observasi untuk mengetahui kelemahan pembelajaran sebelum melakukan penelitian. Observasi dilakukan untuk dapat mengetahui ketetapan tindakan yang akan diberikan dalam rangka meningkatkan keaktifan belajar siswa pada Pelajaran PKn. Dari hasil obeservasi awal bersama teman sejawat menetapkan tindakan untuk meningkatkan keaktifan belajar siswa pada Pelajaran PKn yaitu melalui pembelajaran dengan menggunakan pendekatan pembelajaran PAKEM. Dengan berpatokan pada refleksi awal tersebut, maka dilaksanakan penelitian tindakan kelas (PTK) dengan prosedur sebagai berikut:

Siklus I dilakukan dengan tujuan untuk mencoba penerapan pendekatan pembelajaran PAKEM guna untuk meningkatkan keaktifan belajar siswa pada Pelajaran PKn di Kelas III SD Negeri 060819 Kec. Medan Kota. Adapun langkahlangkahnya sebagai berikut.

Kegiatan yang dilakukan dalam setiap perencanaan ini meliputi:

a. membuat skenario pelaksanaan tindakan berupa rencana pelaksanaan pembelajaran.

b. membuat lembar observasi untuk mengamati aktivitas siswa dan guru dalam proses pembelajaran.

c. menyiapkan media alat bantu mengajar yang diperlukan dalam rangka membantu siswa memahami konsep-konsep PKn dengan baik.

d. mendesain alat evaluasi untuk melihat hasil belajar siswa.

Kegiatan yang dilakukan pada tahap pelaksanaan adalah melaksanakan skenario pembelajaran sesuai skenario pembelajaran yang dibuat. Pendekatan pembelajaran yang digunakan guru adalah pendekatan pembelajaran PAIKEM sesuai dengan materi yang diajarkan pada tiap siklus. Kegiatan yang dilakukan pada tahap ini antara lain:

1. Guru memberikan penjelasan sedikit gambaran tentang materi Pelajaran PKn.

2. Guru menjelaskan cara menyelesaikan tugas yang diberikan peneliti. 
3. Guru memberikan kesempatan kepada siswa untuk bertanya, jika ada penjelasan yang kurang dipahami.

4. Membimbing siswa membuat kesimpulan yang diperoleh.

Observasi dilaksanakan dengan menggunakan lembar observasi yang telah dibuat. Proses observasi dilakukan oleh rekan sejawat peneliti untuk mengamati guru dan siswa dalam kelas selama proses pembelajaran dengan pendekatan pembelajaran PAKEM.

Pada tahap ini dilakukan analisa hasil observasi dan hasil evaluasi untuk mengetahui berhasil atau tidaknya tindakan yang dilakukan. Apabila pelaksanaan siklus I belum tuntas berdasarkan indikator keberhasilan, maka hasil refleksi digunakan sebagai dasar untuk perencanaan siklus berikutnya.

Tahap perencanaan pada siklus II merupakan hasil refleksi dari siklus I. Pada tahap ini peneliti dapat mengetahui seberapa banyak siswa yang kurang aktif dalam belajar. Dan pada tahap ini juga peneliti memfokuskan kesulitan yang dialami siswa pada siklus I.

Analisis data ini dilakukan untuk mengetahui tingkat keaktifan belajar siswa dan keaktifan mengajar guru. Bentuk pengukuran yang dilakukan untuk mengetahui hasil observasi keaktifan belajar siswa dan guru menggunakan distribusi frekwensi sturges (Sudjana, 2004:80)

Range $=$ skor tertinggi - skor terendah

$$
\begin{aligned}
& =24-6 \\
& =18
\end{aligned}
$$

Banyak kelas $=$ ditetapkan 4

$$
\begin{aligned}
\text { Panjang kelas } & =\frac{\text { Range }}{\text { Banyak Kelas }} \\
& =\frac{18}{4}=4,5 \text { ditetapkan } 5
\end{aligned}
$$

Sehingga diperoleh kriteria klasikal keaktifan belajar siswa dan keaktifan guru menerapkan pendekatan pembelajaran:

Tabel 3.3 Tabulasi Skor Kategori Keaktifan Belajar Siswa dan Guru

\begin{tabular}{|c|c|}
\hline Rentang Skor & Keterangan \\
\hline $21-24$ & Sangat Aktif \\
\hline $16-20$ & Aktif \\
\hline $11-15$ & Cukup Aktif \\
\hline $6-10$ & Kurang Aktif \\
\hline
\end{tabular}

\section{HASIL DAN PEMBAHASAN}

Sebelum

penelitian dilaksanakan peneliti mengumpulkan data tentang keaktifan belajar siswa dengan melakukan observasi awal. Dilaksanakan bersama dengan guru Kelas III SD untuk mengetahui kondisi belajar siswa dan tingkat keaktifan belajar siswa dalam mengikuti Pelajaran PKn dengan materi organisasi. Kemudian diperoleh data awal dari hasil observasi sebagai berikut: 
Tabel 4.2 Rekapitulasi Keaktifan Belajar Siswa Pada Kondisi Awal

\begin{tabular}{|c|c|c|c|c|}
\hline NO & $\begin{array}{c}\text { Skor } \\
\text { Keaktifan } \\
\text { Belajar } \\
\text { Siswa }\end{array}$ & $\begin{array}{c}\text { Tingkat } \\
\text { Keaktifan }\end{array}$ & Frekuensi & $\%$ \\
\hline 1 & $21-24$ & $\begin{array}{c}\text { Sangat } \\
\text { Aktif }\end{array}$ & 0 & $0,00 \%$ \\
\hline 2 & $16-20$ & Aktif & 0 & $0,00 \%$ \\
\hline 3 & $11-15$ & $\begin{array}{c}\text { Cukup } \\
\text { Aktif }\end{array}$ & 5 & $22,73 \%$ \\
\hline 4 & $6-10$ & $\begin{array}{c}\text { Kurang } \\
\text { Aktif }\end{array}$ & 17 & $77,27 \%$ \\
\hline & Jumlah & 22 & $100,00 \%$ \\
\hline
\end{tabular}

Berdasarkan data hasil observasi awal di atas maka dapat dijelaskan bahwa keaktifan belajar masih rendah. Dari data diperoleh di Kelas III SD Negeri 060819 Medan Tuntungan diketahui bahwa rata-rata skor keaktifan belajar siswa pada kondisi awal secara klasikal sebesar 9. Keaktifan belajar siswa diketahui tidak terdapat siswa dengan tingkat keaktifan sangat aktif (21 - 24) dan aktif (16 - 20), sedangkan dengan tingkat keaktifan cukup aktif (11 - 15) sebanyak 5 orang siswa dan dengan tingkat keaktifan kurang aktif (6 - 10) sebanyak 17 orang siswa.

Berdasarkan data tersebut dapat disimpulkan bahwa keaktifan belajar siswa Kelas III SD Negeri 060819 Kec. Medan Kota masih tergolong kurang aktif pada mata Pelajaran PKn dengan materi organisasi. Pada pertemuan awal pembelajaran, guru juga menemukan beberapa faktor penghambat yang menyebabkan keaktifan belajar siswa masih tergolong rendah. Adapun faktor tersebut, antara lain: 1) siswa belum memilki hasrat keingintahuan yang cukup sebesar terhadap materi organisasi; 2) siswa malu dan takut salah untuk mengajukan pertanyaan kepada guru; 3) rendahnya daya imajiansi siswa untuk membuat pertanyaan dan mengutarakan pendapat atau ide kepada guru. Setelah melihat data dan kondisi belajar siswa maka telah diperoleh faktor penghambat keaktifan belajar siswa, maka peneliti merencanakan untuk menerapkan Pendekatan Pembelajaran PAKEM untuk meningkatkan keaktifan belajar siswa pada mata Pelajaran PKn dengan materi organisasi.

Penelitian tindakan kelas ini melibatkan satu seorang guru sebagai pengajar yaitu peneliti dan dibantu oleh guru Kelas III SD selaku mitra kolaborator. Guru akan melaksanakan kegiatan pembelajaran di kelas sementara guru kelas bertindak selaku observer kegiatan pembelajaran dan pengamatan terhadap keaktifan belajar siswa dan keaktifan peneliti selama pembelajaran berlangsung.

Kegiatan yang dilakukan guru dalam perencanaan adalah: merencanakan pendekatan pembelajaran yang akan diterapkan dalam proses belajar mengajar; menyusun RPP dengan menggunakan pendekatan pembelajaran PAKEM; mempersiapkan sumber materi pelajaran, bahan ajar, dan media gambar yang dibutuhkan selama 
kegiatan pembelajaran berlangsung; mempersiapkan lembar observasi penerapan pendekatan pembelajaran PAKEM dan lembar observasi keaktifan belajar siswa, serta menyiapkan alat dokumentasi.

Pada kegiatan Inti, guru memberikan penjelasan mengenai tujuan dari materi pelajaran yang akan dibahas. Adapun tujuan dari pembelajaran pada pertemuan pertama adalah siswa dapat menjelaskan Organisasi melalui kerja kelompok menggunakan bahasa sendiri dengan benar. Untuk memotivasi siswa, guru memotivasi siswa dengan mengajak siswa bernyanyi bersama dengan lagu "Lihat Kebunku". Kemudian siswa dibagi ke dalam kelompok belajar. Dengan perincian masing-masing kelompok terdiri dari 4 orang secara heterogen, baik jenis kelamin maupun prestasi belajar siswa. Guru membagi siswa kedalam kelompok sebanyak 4 orang, karena melihat ketersediaan alokasi waktu yang terbatas dan memungkinkan hanya beberapa kelompok saja yang memilki kesempatan untuk mempresentasikan hasil kerja kelompok di depan kelas. Dengan demikian ada 5 kelompok belajar dengan masalah yang berbedabeda.

Sebelum bergabung dalam kelompok siswa mendengarkan penyajian informasi mengenai materi pelajaran yang akan didiskusikan.
Penyajian materi dilakukan dengan cara membaca buku paket oleh siswa dilanjutkan penjelasan dari peneliti. Sumber dari buku yang lain juga tidak lupa untuk dibawa sebagai tambahan dalam pengerjaan kerja kelompok. Kemudian siswa diminta bergabung sesuai kelompok masing - masing. Setelah bergabung ke dalam kelompok masing - masing, peneliti memberikan penjelasan mengenai tata cara kerja kelompok. Kemudian siswa diberikan tugas untuk di kerjakan dalam masing-masing. Selanjutnya siswa melaksanakan kerja kelompok dengan tenang.

Guru pun memberikan bimbingan dan arahan bila ada hal yang tidak diketahui oleh siswa serta cara membuat laporan berupa tulisan sederhana. Adapun isi dari laporan kelompok adalah dengan menuliskan terlebih dahulu nama kelompok, nama ketua kelompok dan sekretaris kelompok dan nama - nama anggota kelompok. Kemudian diikuti hasil kerja kelompok dibagian akhir. Kelompok diberikan waktu \pm 10 menit membuat hasil kerja kelompoknya.

Pada kegiatan akhir pembelajaran, guru dan siswa menyimpulkan materi pelajaran. Apabila ada hal yang kurang dipahami siswa pada soal, guru memberikan arahan dan penjelasan. Setelah selesai, siswa diminta mengumpulkan jawaban kuis. 
Kemudian guru memberikan tugas (PR) kepada siswa dan memberi arahan untuk mengerjakan dirumah dan dikumpul sebelum peneliti datang dan di kumpul di meja guru.

\section{Selama pembelajaran}

berlangsung, peneliti dibantu oleh guru kelas melakukan observasi untuk melihat aktifitas siswa dalam pelaksanaan pembelajaran yang dilakukan oleh guru. Selama melaksanakan kerja kelompok, guru juga mengawasi siswa mengerjakan tugas kelompoknya. Guru membantu siswa yang mengalami kesulitan dalam menyusun laporan. Agar pembahasan tidak keliru maka guru memberikan arahan dan meluruskan pandangan siswa mengenai materi yang dibahas. Guru melakukan penilaian aktifitas belajar siswa dibantu oleh guru kelas.

Berikut hasil observasi keaktifan belajar siswa untuk mengetahui perubahan perilaku keaktifan siswa dengan menggunakan Pendekatan PAKEM pada Siklus I Pertemuan 1:

Tabel 4.4 Rekapitulasi Keaktifan Belajar Siswa Siklus I Pertemuan 1

\begin{tabular}{|c|c|c|c|c|}
\hline NO & $\begin{array}{c}\text { Skor } \\
\text { Keaktifan } \\
\text { Belajar } \\
\text { Siswa }\end{array}$ & Kategori & Frekuensi & $\%$ \\
\hline 1 & $21-24$ & $\begin{array}{c}\text { Aktif } \\
\text { Aktif }\end{array}$ & 0 & $0,00 \%$ \\
\hline 2 & $16-20$ & 1 & $4,55 \%$ \\
\hline 3 & $11-15$ & $\begin{array}{c}\text { Aktif } \\
\text { Akup }\end{array}$ & 6 & $27,27 \%$ \\
\hline 4 & $6-10$ & $\begin{array}{c}\text { Kurang } \\
\text { Aktif }\end{array}$ & 15 & $68,18 \%$ \\
\hline \multicolumn{7}{|c|}{ Jumlah } & \multicolumn{2}{|c|}{} \\
\hline
\end{tabular}

Dari data hasil observasi terhadap keaktifan belajar siswa Kelas III SD Negeri 060819 Kec. Medan Kota dapat diketahui bahwa di dapatkan rata-rata keaktifan belajar siswa pada Siklus I Pertemuan 1 yaitu 10. Tidak terdapat siswa dengan ratarata dengan tingkat keaktifan sangat aktif (21-24), sebanyak 1 orang siswa dengan dengan tingkat keaktifan aktif (16-20), sebanyak 6 orang siswa dengan tingkat keaktifan cukup aktif (15-20) dan dengan tingkat keaktifan kurang aktif (6-10) sebanyak 15 orang siswa. Selain pelaksanaan observasi terhadap keaktifan belajar sisiwa, guru juga mempersiapkan lembar observasi untuk guru kelas dalam memberikan penilain terhadap kegiatan pembelajaran yang telah dilaksanakan peneliti.

Berdasarkan lembar observasi kegiatan mengajar yang dilaksanakan oleh guru pada Siklus I Pertemuan 1 pada materi organisasi, diperoleh tingkat keaktifan guru sebesar 18 termasuk kategori aktif. Berdasarkan lembar observasi aspek yang perlu diperbaiki adalah kegiatan evaluasi dan penghargaan kelompok terbaik.

Kegiatan yang dilakukan guru dalam perencanaan adalah: merencanakan pendekatan pembelajaran yang akan diterapkan dalam proses belajar mengajar; menyusun RPP dengan menggunakan pendekatan pembelajaran PAKEM; mempersiapkan sumber materi 
pelajaran, bahan ajar, dan media gambar yang dibutuhkan selama kegiatan pembelajaran berlangsung; mempersiapkan lembar observasi penerapan pendekatan pembelajaran PAKEM dan lembar observasi keaktifan belajar siswa serta menyiapkan alat dokumentasi.

Selama

pembelajaran

berlangsung, peneliti dibantu oleh guru kelas melakukan observasi untuk melihat aktifitas siswa dalam pelaksanaan pembelajaran yang dilakukan oleh guru. Selama melaksanakan kerja kelompok, guru juga mengawasi siswa mengerjakan tugas kelompoknya. Guru membantu siswa yang mengalami kesulitan dalam menyusun laporan. Agar pembahasan tidak keliru maka guru memberikan arahan dan meluruskan pandangan siswa mengenai materi yang dibahas. Guru melakukan penilaian aktifitas belajar siswa dibantu oleh guru kelas.

Berikut hasil observasi keaktifan belajar siswa untuk mengetahui perubahan perilaku keaktifan belajar siswa dengan diterapkannya pendekatan pembelajaran PAKEM pada Siklus I Pertemuan 2.

Tabel 4.7 Rekapitulasi Keaktifan Belajar Siswa Siklus I Pertemuan 2

\begin{tabular}{|c|c|c|c|c|}
\hline NO & $\begin{array}{c}\text { Skor } \\
\text { Keaktifan } \\
\text { Belajar } \\
\text { Siswa }\end{array}$ & Kategori & Frekuensi & $\%$ \\
\hline 1 & $21-24$ & Sangat & 0 & $0,00 \%$ \\
\hline
\end{tabular}

\begin{tabular}{|c|c|c|c|c|}
\hline & & Aktif & & \\
\hline 2 & $16-20$ & Aktif & 5 & $22,73 \%$ \\
\hline 3 & $11-15$ & $\begin{array}{c}\text { Cukup } \\
\text { Aktif }\end{array}$ & 11 & $50,00 \%$ \\
\hline 4 & $6-10$ & $\begin{array}{c}\text { Kurang } \\
\text { Aktif }\end{array}$ & 6 & $27,27 \%$ \\
\hline \multicolumn{2}{|c|}{ Jumlah } & $\mathbf{2 2}$ & \multicolumn{2}{|c|}{$\mathbf{1 0 0 , 0 0 \%}$} \\
\hline
\end{tabular}

Dari data hasil observasi terhadap keaktifan belajar siswa Kelas III SD Negeri 060819 Kec. Medan Kota dapat diperoleh skor rata-rata keaktifan belajar siswa pada Siklus I Pertemuan II sebesar 13. Tidak terdapat siswa dengan rata-rata dengan tingkat keaktifan sangat aktif (21-24), sebanyak 5 orang siswa dengan dengan tingkat keaktifan aktif (16-20), sebanyak 11 orang siswa dengan tingkat keaktifan cukup aktif (15-20) dan dengan tingkat keaktifan kurang aktif (6-10) sebanyak 6 orang siswa.

Selain mengobservasi keaktifan belajar siswa, guru juga mempersiapkan lembar observasi untuk digunakan guru sebagai observer peneliti ketika melaksanakan kegiatan pembelajaran di kelas dengan menerapkan pendekatan pembelajaran.

Berdasarkan lembar hasil observasi siklus I pertemuan 2 materi perlunya perumusan dasar negara dengan menerapkan pendekatan pembelajaran PAKEM diketahui bahwa diperoleh skor keaktifan guru sebesar 20 termasuk kategori aktif.

Pada observasi siswa siklus I pertemuan 1 secara klasikal rata- rata skor keaktifan belajar siswa sebesar 
10 dengan tingkat keaktifan rendah.

Dan pada pertemuan 2 terdapat peningkatan rata-rata skor keaktifan belajar siswa secara klasikal sebesar 13 dengan tingkat keaktifan masih rendah. Hal-hal yang teramati bahwa dalam proses pembelajaran siswa belum memiliki daya imajinasi yang kuat untuk memahami materi pelajaran dengan baik. Hingga siswa tidak mampu melihat suatu permasalahan dari bersebagai sudut pandang. Banyak siswa membuat pertanyaan namun antara pertanyaan satu siswa dengan siswa yang lain memilki maksud yang sama, sehingga jawaban untuk pertanyaan itu berulang-ulang dijawab. Ditambah keinginan untuk menemukan sumber bacaan lain masih kurang. Hanya beberapa kelompok yang memilki sumber bacaan lain. Bahkan peneliti masih sering menunjuk siswa untuk memberikan pertanyaan dan menunjuk siswa tertentu untuk menjawab pertanyaan, hal ini disebabkan siswa belum terbiasa dengan suasana belajar kooperatif dan seakan belum bebas menyatakan pendapat karena siswa masih malu dan takut salah.

Berdasarkan hasil observasi yang telah dilakukan pada siklus I, maka diperoleh perbandingan hasil observasi keaktifan belajar siswa pada pertemuan 1 dan pertemuan 2 sebagai berikut:

\section{Tabel 4.9 Rekapitulasi Keaktifan Belajar Siswa Siklus I}

\begin{tabular}{|c|c|c|}
\hline Siklus I & $\begin{array}{c}\text { Jumlah } \\
\text { Skor }\end{array}$ & $\begin{array}{c}\text { Rata - Rata } \\
\text { Skor }\end{array}$ \\
\hline Pertemuan 1 & 228 & 10 \\
\hline Pertemuan 2 & 282 & 13 \\
\hline
\end{tabular}

Guru kelas juga mengobservasi peneliti, pada observasi siklus I pertemuan 1 diperoleh skor keaktifan guru mengajar sebesar 18 dan pada siklus I pertemuan 2 diperoleh skor keaktifan guru mengajar sebesar 20. Pada siklus I hal yang perlu ditingkatkan oleh guru adalah mengenai pengorganisasian kelompok belajar siswa. Dalam membentuk kelompok terkadang membutuhkan waktu lama \pm 10 menit, hal ini dikarenakan siswa belum terbiasa bekerja dalam kelompok. serta dalam melaksanakan evaluasi, peneliti masih membagikan berupa soal kuis kepada setiap siswa. Tidak langsung mengajukan pertanyaan kepada siswa sebagai kuis cepat-tepat. Dan dalam hal memberikan penghargaan kepada siswa dan kelompok terbaik, peneliti terkadang kekurangan waktu untuk melaksanakannya.

Berdasarkan hasil observasi yang telah dilakukan pada siklus I, maka diperoleh perbandingan hasil observasi keaktifan guru mengajar pada pertemuan 1 dan pertemuan 2 sebagai berikut: 
Tabel 4.10 Rekapitulasi Keaktifan Guru Mengajar Siklus I

\begin{tabular}{|c|c|}
\hline Siklus I & $\begin{array}{c}\text { Jumlah Skor Keaktifan } \\
\text { Mengajar }\end{array}$ \\
\hline Pertemuan 1 & 18 \\
\hline Pertemuan 2 & 20 \\
\hline
\end{tabular}

Pada siklus II pertemuan I, upaya yang dilakukan adalah meningkatkan keaktifan belajar siswa dengan materi pokok Organisasi dengan semaksimal mungkin khususnya terhadap siswa yang kategori cukup aktif menjadi kriteria aktif.

Kegiatan yang dilakukan guru dalam perencanaan adalah: merencanakan model pembelajaran yang akan diterapkan dalam proses belajar mengajar, menyusun RPP dengan menggunakan menerapkan pendekatan PAKEM mempersiapkan sumber materi pelajaran, bahan ajar, dan media gambar yang dibutuhkan selama kegiatan pembelajaran berlangsung, mempersiapkan lembar observasi penerapan pendekatan PAKEM dan lembar observasi keaktifan belajar siswa, serta menyiapkan alat dokumentasi.

Kegiatan yang dilaksanakan pada tahap ini adalah melaksanakan tindakan sesuai dengan yang telah direncanakan, dimana pelaksanaan tindakan pada siklus II dilakukan banyak dua kali pertemuan. tiap pertemuan berlangsung lama dua jam pelajaran ( 2 x 35 menit). Pelaksanaan tindakan Siklus II terdiri dari kegiatan pendahuluan, kegiatan inti dan kegiatan akhir. Pada kegiatan pendahuluan peneliti mengisi daftar kelas, berdoa bersama siswa;,membimbing siswa untuk menjaga kebersihan kelas. Kemudian guru memberikan pertanyaan kepada siswa sebagai apersepsi mengenai organisasi. Sebagian siswa sudah berlomba untuk mengangkat tangan untuk menjawab pertanyaan peneliti. Dan sudah berebut menjawab pertanyaan, walaupun berebut namun ketertiban dan keamanan masih terjaga.

Pada kegiatan inti, guru memberikan penjelasan tentang macam-macam sumber daya alam dan jenis-jenis sumber daya alam. Kegiatan membaca buku paket diawali terlebih dahulu dilanjutkan dengan penjelasan. Pada kegiatan akhir, peneliti dan siswa membuat kesimpulan pelajaran. Kemudian siswa di ingatkan untuk mengulang lagi materi pembahasan dengan membaca kembali buku di rumah. Dan mengucapkan salam.

Selama pembelajaran berlangsung, peneliti dibantu oleh guru kelas melakukan observasi untuk melihat aktifitas siswa dalam pelaksanaan pembelajaran yang dilakukan oleh guru. Guru kelas melakukan observasi kegiatan Mengajar Guru sesuai dengan indikator pada lembar observasi. 
Selama melaksanakan kerja kelompok, guru juga mengawasi siswa mengerjakan tugas kelompoknya.

Berikut hasil observasi keaktifan belajar siswa untuk mengetahui perubahan perilaku keaktifan belajar siswa dengan menggunakan penerapan pendekatan PAKEM pada Siklus II Pertemuan 1:

Tabel 4.12 Rekapitulasi Keaktifan Belajar Siswa Siklus II Pertemuan 1

\begin{tabular}{|c|c|c|c|c|}
\hline NO & $\begin{array}{c}\text { Skor } \\
\text { Keaktifan } \\
\text { Belajar } \\
\text { Siswa }\end{array}$ & Kategori & Frekuensi & $\%$ \\
\hline 1 & $21-24$ & $\begin{array}{c}\text { Sangat } \\
\text { Aktif }\end{array}$ & 5 & $22,73 \%$ \\
\hline 2 & $16-20$ & Aktif & 9 & $40,91 \%$ \\
\hline 3 & $11-15$ & $\begin{array}{c}\text { Cukup } \\
\text { Aktif }\end{array}$ & 5 & $22,73 \%$ \\
\hline 4 & $6-10$ & $\begin{array}{c}\text { Kurang } \\
\text { Aktif }\end{array}$ & 3 & $13,64 \%$ \\
\hline & mlah & \multicolumn{2}{|c|}{22} & $100,00 \%$ \\
\hline
\end{tabular}

Dari data hasil observasi terhadap keaktifan belajar siswa Kelas III SD Negeri 060819 Kec. Medan Kota dapat diketahui bahwa diperoleh rata-rata keaktifan belajar siswa pada Siklus II Pertemuan I yaitu 16. Terdapat 5 orang siswa dengan rata-rata dengan tingkat keaktifan sangat aktif (21-24), sebanyak 9 orang siswa dengan dengan tingkat keaktifan aktif (1620), sebanyak 5 orang siswa dengan tingkat keaktifan cukup aktif (15-20) dan sebanyak 3 orang siswa dengan tingkat keaktifan kurang aktif (6-10).
Selain melakukan observasi keaktifan belajar siswa, guru juga mempersiapkan lembar observasi untuk digunakan guru sebagai observer guru ketika melaksanakan proses pembelajaran di kelas dengan menggunakan penerapan pendekatan PAKEM. Berdasarkan lembar observasi kegiatan mengajar guru di dalam kelas pada siklus ii pertemuan 1 pada materi organisasi dengan menggunakan penerapan pendekatan PAKEM diperoleh skor keaktifan guru mengajar sebesar 22.

Pada siklus II pertemuan II, upaya yang dilakukan adalah meningkatkan keaktifan belajar siswa dengan materi pokok Organisasi dengan semaksimal mungkin khususnya terhadap siswa kategori cukup aktif menjadi aktif dan siswa yang aktif menjadi sangat aktif.

Kegiatan yang dilakukan guru dalam perencanaan adalah: merencanakan model pembelajaran yang akan diterapkan dalam proses belajar mengajar; menyusun RPP dengan menggunakan menerapkan pendekatan PAKEM mempersiapkan sumber materi pelajaran, bahan ajar, dan media gambar yang dibutuhkan selama kegiatan pembelajaran berlangsung, mempersiapkan lembar observasi penerapan pendekatan PAKEM dan lembar observasi keaktifan belajar siswa, serta menyiapkan alat dokumentasi.

p-ISSN 2407-4934 e-ISSN 2355-1747 
Pada pertemuan kedua, guru melaksanakan kegiatan pendahuluan, kegiatan inti dan kegiatan akhir pada proses pembelajaran. Pada kegiatan inti siswa sudah membentuk kelompok dengan rapi dan cepat setelah ada instruksi dari peneliti. Guru pun memberikan apresiasi atas kerja sama yang baik dalam kelopok belajar siswa. Kemudian guru meminta salah satu kelompok untuk maju menampilkan lagu yang telah mereka siapkan pada pertemuan sebelumnya untuk menambah motivasi belajar siswa. Selanjutnya peneliti dan siswa membaca secara bersama-sama buku paket. Kemudian memberikan penjelasan kepada siswa mengenai materi yang diajarkan.

Pemberian penghargaan kepada kelompok terbaik berdasarkan pengamatan peneliti dan guru kelas sebagai hasil evaluasi proses pembelajaran. Guru pun memberikan berupa hadiah kepada kelompok tersebut dan tepuk tangan meriah dari seluruh siswa selaku peserta didik dan guru kelas. Guru memberikan hadiah agar siswa semakin termotivasi dalam belajar.

Diakhir kegiatan pembelajaran guru meminta siswa untuk menyimpulkan kegiatan pembelajaran. Dilanjtukan dengan memberikan PR untuk dikerjakan di rumah. Peneliti tidak lupa mengingatkan siswa untuk mengulang-ulang pelajaran kembali di rumah dengan membaca buku. Peneliti mengucapkan salam dan terimakasih.

Berikut hasil observasi keaktifan belajar siswa pada Siklus II Pertemuan II dengan menerapkan pendekatan PAKEM pada materi organisasi.

Tabel 4.15 Rekapitulasi Keaktifan Belajar Siswa Siklus II Pertemuan II

\begin{tabular}{|c|c|c|c|c|}
\hline No & $\begin{array}{c}\text { Skor } \\
\text { Keaktifan } \\
\text { Belajar } \\
\text { Siswa }\end{array}$ & Kategori & Frekuensi & $\%$ \\
\hline 1 & $21-24$ & $\begin{array}{c}\text { Sangat } \\
\text { Aktif }\end{array}$ & 10 & $45,45 \%$ \\
\hline 2 & $16-20$ & Aktif & 8 & $36,36 \%$ \\
\hline 3 & $11-15$ & $\begin{array}{c}\text { Cukup } \\
\text { Aktif }\end{array}$ & 3 & $13,64 \%$ \\
\hline 4 & $6-10$ & $\begin{array}{c}\text { Kurang } \\
\text { Aktif }\end{array}$ & 1 & $4,55 \%$ \\
\hline \multicolumn{7}{|c|}{ Jumlah } & 22 & \multicolumn{2}{|c|}{$\mathbf{1 0 0 , 0 0 \%}$} \\
\hline
\end{tabular}

Dari data hasil observasi terhadap keaktifan belajar siswa Kelas III SD Negeri 060819 Kec. Medan Kota dapat diperoleh skor rata-rata keaktifan belajar siswa pada Siklus II Pertemuan II sebesar 19. Terdapat 10 orang siswa dengan ratarata dengan tingkat keaktifan sangat aktif (21-24), sebanyak 8 orang siswa dengan dengan tingkat keaktifan aktif (16-20), sebanyak 3 orang siswa dengan tingkat keaktifan cukup aktif (15-20) dan 1 orang siswa dengan tingkat keaktifan kurang aktif (6-10).

Selain melakukan observsi keaktifan belajar siswa, guru juga mempersiapkan lembar observasi 
untuk kegiatan mengajar guru ketika melaksanakan proses pembelajaran di kelas dengan menerapkan pendekatan pembelajaran PAKEM.

Berdasarkan lembar hasil observasi kegiatan Mengajar Guru pada siklus II pertemuan 2 dengan materi organisasi diketahui bahwa diperoleh skor keaktifan guru mengajar sebesar 23 termasuk kategori sangat aktif. Pada tabel observasi dapat dilihat aspek yang perlu diperbaiki adalah pelaksanaan bimbingan kelompok belajar dan hasil karya yang merupakan pemikiran anak sendiri dan untuk melibatkan siswa langsung dengan lingkungan sekitar sekolah atau tempat tinggal.

Berdasarkan hasil pengamatan untuk siswa diketahui bahwa telah tercipta kerjasama yang baik antar siswa dan antara siswa dan peneliti. Pada observasi keaktifan belajar siswa siklus II pertemuan 1 secara klasikal ratarata skor keaktifan belajar siswa sebesar 16, pada siklus II pertemuan 2 secara klasikal rata-rata skor keaktifan belajar siswa sebesar meningkat menjadi 19. Dengan demikian, hasil tindakan siklus II diperoleh kesimpulan bahwa pembelajaran PKn dengan menerapkan pendekatan pembelajaran PAKEM dapat meningkatkan keaktifan belajar siswa dengan materi organisasi di
Kelas III SD Negeri 060819 Kec. Medan Kota T.A 2017/2018. Dari hasil observasi yang telah dilakukan pada siklus II, maka dengan menerapkan pendekatan pembelajaran PAKEM di dapat data sebagai berikut:

Tabel 4.17 Tabel Keaktifan Belajar Siswa Siklus II

\begin{tabular}{|c|c|c|}
\hline Siklus II & Jumlah Skor & $\begin{array}{c}\text { Rata - Rata } \\
\text { Skor }\end{array}$ \\
\hline Pertemuan 1 & 361 & 16 \\
\hline Pertemuan 2 & 412 & 19 \\
\hline
\end{tabular}

Dari hasil observasi yang dilakukan guru kelas terhadap guru, pada observasi peneliti siklus II pertemuan 1 skor keaktifan guru mengajar sebesar 22 dan pada siklus II pertemuan 2 skor keaktifan guru mengajar meningkat menjadi 23 dengan kriteria sangat baik. Dimana peneliti mampu memberi motivasi belajar bagi peserta didik selama kegiatan pembelajaran berlangsung. Guru mampu mengorganisasikan siswa di dalam kelompok hingga siswa mampu membentuk kelompok belajar dengan rapi. Serta peneliti mampu memberikan penghargaan bagi kelompok terbaik dengan memberikan berupa hadiah, hingga siswa makin termotivasi untuk terus belajar. Semua aspek yang diamati telah dilaksanakan dengan baik. 
Tabel 4.18 Rekapitulasi Keaktifan Peneliti Mengajar Siklus II

\begin{tabular}{|c|c|}
\hline Siklus II & $\begin{array}{c}\text { Jumlah Skor Keaktifan } \\
\text { Mengajar }\end{array}$ \\
\hline Pertemuan 1 & 18 \\
\hline Pertemuan 2 & 20 \\
\hline
\end{tabular}

\section{Pembahasan}

Pada siklus I pertemuan 1 keaktifan belajar siswa pada mata Pelajaran PKn masih termasuk kurang aktif dengan rata-rata skor keaktifan belajar siswa secara klasikal yaitu 10 . Dan pada siklus I pertemuan 2 ratarata skor keaktifan belajar siswa secara klasikal adalah 13 masih termasuk cukup aktif. Upaya yang harus dilakukan untuk meningkatkan keaktifan belajar siswa yaitu peneliti harus mengoptimalkan proses pembelajaran kepada siswa dengan untuk materi organisasi melalui penerapan pendekatan pembelajaran PAKEM.

Selanjutnya

guru melaksanakan siklus II sebagai perbaikan dari siklus I untuk melihat perkembangan tingkat keaktifan belajar siswa pada mata Pelajaran PKn dengan materi organisasi dengan menggunakan menerapkan pembelajaran PAKEM. Pada Siklus II pertemuan 1 keaktifan belajar siswa sudah mengalami peningkatan, ratarata skor keaktifan belajar siswa secara klasikal sebesar 16 sudah termasuk kategori aktif. Dan pada
Siklus II pertemuan 2 diperoleh skor keaktifan belajar siswa sebesar 19 . Hal ini menunjukkan bahwa pelakasanaan kegiatan proses belajar mengajar telah berhasil meningkatkan keaktifan belajar siswa. Penggunaan metode PAKEM dalam penelitian ini dapat meningkatkan keaktifan belajar siswa dengan materi organisasi pada mata Pelajaran PKn. Dengan digunakannya pendekatan pembelajaran PAKEM juga mampu memberi motivasi belajar bagi siswa sesuai dengan materi pembelajaran yang sedang dibahas. Selain itu, melalui model pembelajaran ini siswa dapat menumbuhkan daya imajinasi siswa dalam belajar untuk mengemukakan pertanyaan dan memberikan pertanyaan sebagai bentuk rasa ingin tahu siswa terhadap materi pelajaran yang dang dibahas.

Dengan demikian berdasarkan hasil penelitian yang dilakukan di SD Negeri 060819 Kec. Medan Kotabagi siswa Kelas III SD dengan materi organisasi dengan menggunakan pendekatan pembelajaran PAKEM dapat meningkatkan keaktifan belajar siswa pada mata Pelajaran PKn.

Berdasarkan hasil observasi pada siklus i dan siklus II yang telah guru. Maka diperoleh data sebagai berikut: 
Tabel 4.19 Rekapitulasi Skor Keaktifan Belajar Siswa Siklus I dan Siklus II

\begin{tabular}{|c|c|c|c|c|c|c|}
\hline \multirow{3}{*}{ No. } & \multirow{3}{*}{$\begin{array}{c}\text { Nomor } \\
\text { Responden }\end{array}$} & \multicolumn{5}{|c|}{ Skor Keaktifan Belajar Siswa } \\
\hline & & \multirow{2}{*}{$\begin{array}{c}\text { Kondisi } \\
\text { Awal }\end{array}$} & \multicolumn{2}{|c|}{ Siklus I } & \multicolumn{2}{|c|}{ Siklus II } \\
\hline & & & Pert. 1 & Pert. 2 & Pert. 1 & Pert. 2 \\
\hline 1 & Hani S. & 6 & 8 & 10 & 14 & 16 \\
\hline 2 & Rapah A. & 9 & 11 & 13 & 15 & 17 \\
\hline 3 & Melvi R. & 10 & 11 & 13 & 16 & 21 \\
\hline 4 & Febby H. & 11 & 12 & 16 & 21 & 22 \\
\hline 5 & Fauzan A & 8 & 9 & 13 & 17 & 21 \\
\hline 6 & Angga Jhon & 10 & 11 & 13 & 18 & 21 \\
\hline 7 & Cristian F. & 8 & 12 & 14 & 19 & 22 \\
\hline 8 & Gadi S. & 15 & 16 & 18 & 21 & 22 \\
\hline 9 & Suci M. & 14 & 15 & 17 & 21 & 22 \\
\hline 10 & Putriana G. & 6 & 8 & 7 & 9 & 11 \\
\hline 11 & Cindy $\mathrm{M}$. & 7 & 11 & 14 & 16 & 19 \\
\hline 12 & Samah W. & 14 & 15 & 16 & 22 & 23 \\
\hline 13 & Raihan & 6 & 7 & 14 & 18 & 20 \\
\hline 14 & Hilton $\mathrm{T}$. & 6 & 7 & 10 & 14 & 17 \\
\hline 15 & Fahmi A. & 6 & 7 & 8 & 11 & 12 \\
\hline 16 & Andika P. & 13 & 14 & 17 & 21 & 23 \\
\hline 17 & Diana F. & 8 & 10 & 13 & 17 & 20 \\
\hline 18 & Dirly W. & 6 & 7 & 8 & 10 & 14 \\
\hline 19 & Fathin A. & 6 & 9 & 12 & 14 & 16 \\
\hline 20 & Radit S. & 6 & 8 & 9 & 12 & 15 \\
\hline 21 & Anggun & 6 & 7 & 12 & 16 & 17 \\
\hline 22 & Fandi. A & 12 & 13 & 15 & 19 & 21 \\
\hline \multicolumn{2}{|c|}{ Jumlah Skor } & 193 & 228 & 282 & 361 & 412 \\
\hline \multicolumn{2}{|c|}{ Rata - Rata Skor } & 9 & 10 & 13 & 16 & 19 \\
\hline \multicolumn{2}{|c|}{ Tingkat Keaktifan } & $\begin{array}{c}\text { Kurang } \\
\text { Aktif }\end{array}$ & $\begin{array}{c}\text { Kurang } \\
\text { Aktif }\end{array}$ & $\begin{array}{l}\text { Cukup } \\
\text { Aktif }\end{array}$ & Aktif & Aktif \\
\hline
\end{tabular}

\section{SIMPULAN}

Berdasarkan hasil penelitian dan pengamatan data penelitian yang diperoleh terhadap penigkatan keaktifan belajar siswa Kelas III SD Negeri 060819 Kec. Medan Kota dengan materi Organisasi. Maka kesimpulan dari penelitian ini adalah: 1. Dengan menerapkan
pendekatan PAKEM pada mata pelajaran PKn dengan materi organisasi dapat meningkatkan keaktifan 
belajar siswa Kelas III SD Negeri 060819 Kec. Medan Kota Tahun Ajaran 2017/2018.

2. Rata-rata skor keaktifan belajar siswa pada mata Pelajaran PKn dengan organisasi pada kondisi awal sebesar 9 dan 77,27\% kategori kurang aktif, pada Siklus I Pertemuan 1 dengan rata - rata skor keaktifan belajar siswa sebesar 10 dan $68,18 \%$ kategori kurang aktif. Pada siklus I pertemuan 2 diperoleh rata- rata skor keaktifan belajar siswa adalah 13 dan $50 \%$ termasuk kategori cukup aktif.

3. Pada Siklus II Pertemuan 1 diperoleh rata-rata skor keaktifan belajar siswa sebesar 16 dan 40,91\% sudah termasuk

kategori aktif. Pada siklus II pertemuan 2 diperoleh ratarata skor keaktifan belajar siswa sebesar 19 dan 45,45\% yang sudah termasuk kategori aktif.

Berdasarkan hasil penelitian yang telah dilakukan, maka peneliti menyarankan:

1. Bagi guru supaya menerapkan pendekatan pembelajaran PAKEM dalam upaya meningkatkan keaktifan belajar siswa hingga anak memiliki rasa ingin tahu yang luas terhadap materi pelajaran dan dengan daya imajinasi siswa, siswa mampu membuat pertanyaan yang baik dan memilki keberanian menyampaikan pendapat di dalam kerja kelompok.

2. Bagi guru agar mampu menggunakan bersebagai model pembelajaran yang bervarisi dalam menyampaikan materi pelajaran kepada siswa laku peserta didik.

3. Bagi pihak sekolah untuk memperhatikan akan kebutuhan belajar peserta didik baik sarana maupun prasana supaya dilengkapi demi mencapai tujuan pendidikan yang diharapkan.

4. Bagi siswa untuk membuat siswa agar lebih kreatif dalam berinteraksi dengan teman, guru, dan lingkungan dan menambah pengetahuan dan pengalaman belajar dalam meningkatkan keaktifan belajar PKn.

\section{DAFTAR RUJUKAN}

Asmani Jamal Ma'mur. 2010. 7 Tips Aplikasi PAKEM. Diva Press.

Dimyati, dkk. 2009. Belajar dan Pembelajaran. Jakarta: Rineka Cipta. 
Hamalik Oemar. 1994. Kurikulum dan Pembelajaran. Jakarta: Bumi Aksara.

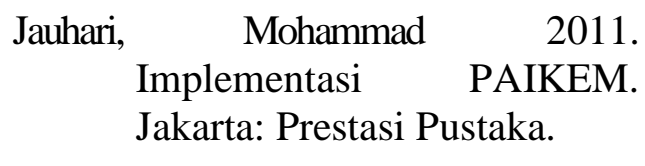

Kirton. 1976. Metodologi Pembelajaran Aktif, Kratif, Efektif dan Menyenangkan (PAKEM). Internet.

Muhibbinsyah. 2010. Psikologi Pendidikan. Bandung: Remaja Rosdakarya.
Nana Sudjana. 2004. Dasar-Dasar Proses Belajar Mengajar. Bandung: Sinar Baru.

Slameto. 2003. Belajar dan faktorFaktor yang Mempengaruhinya. Jakarta: PT Rineka Cipta.

Suharsimi, Arikunto. 2008. Penelitian Tindakan Kelas. Jakarta: Bumi Aksara.

Winastwan Gora, dan Sunarto. 2009. PAKEMATIK. Jakarta: Elex Media Komputindo. 